\title{
CANCER
}

\section{Associated changes of lipid peroxidation and transforming growth factor $\beta 1$ levels in human colon cancer during tumour progression}

\author{
F Biasi, L Tessitore, D Zanetti, J C Cutrin, B Zingaro, E Chiarpotto, N Zarkovic, \\ G Serviddio, G Poli
}

See end of article for authors' affiliations

\section{Correspondence to:} Professor G Poli,

Department of Clinical and Biological Sciences of the

University of Torino, S Luigi

Gonzaga Hospital,

Regione Gonzole 10,

10143 Orbassano, Torino,

Italy; giuseppe.poli@unito.it

Accepted for publication

5 June 2001

\begin{abstract}
Background: During neoplastic progression, alterations in transforming growth factor $\beta 1$ (TGF- $\beta 1$ ) dependent control of cell growth may be an important mechanism of selective proliferation of transformed cellular clones. Defective regulation of TGF- $\beta 1$ receptors has been reported to occur in a number of human malignant tumours while little is known of the actual levels of this growth inhibitory cytokine in cancer. On the basis of the demonstrated ability of major lipid peroxidation products such as 4-hydroxynonenal to modulate TGF- $\beta 1$ expression and synthesis, we speculated that decreased lipid oxidation, as frequently observed in neoplastic tissues, would contribute to the selective promotion of tumour growth through decreased expression of the cytokine within the tumour mass.

Aims: To seek a possible association between steady state levels of major aldehydic end products of lipid peroxidation and TGF- $\beta 1$ content in human colon cancer at different stages of growth.

Patients and methods: Tissue biopsies from 15 adult patients with colon adenocarcinoma of different TNM and $G$ stagings were compared with regard to lipid peroxidation aldehydes and net TGF- $\beta 1$ levels. For a more comprehensive analysis, cytokine type I and II receptors were measured in tumour biopsies. In one set of experiments, to support the conclusions, the apoptotic effect of TGF- $\beta 1$ was evaluated in a human colon cancer cell line, CaCo-2, retaining receptor changes consistent with those observed in cancer patients.

Results: With the exception of two extremely advanced cases (T4/G3) in which tissue levels of lipid peroxidation were within the normal range, 4-hydroxynonenal was significantly decreased in all other cancer specimens. Consistent with lipid peroxidation levels, TGF- $\beta 1$ protein was markedly decreased or even negligible compared with the corresponding normal tissue surrounding the tumour in all tested biopsies except for the two T4/G3 colon cancers in which cytokine content was again within the normal range. As regards TGF- $\beta 1$ receptors, both in tumour sections and CaCo-2 cells, downregulation was greater for TGF- $\beta 1$ receptor I than for receptor II. Of note, in CaCo-2 cells, incubation with appropriate doses of TGF- $\beta 1$ led to marked nuclear fragmentation and apoptosis.

Conclusions: Evasion of human colon cancer cells from TGF- $\beta 1$ mediated growth inhibition appears to be due not only to downregulation of TGF- $\beta 1$ receptors, which is inconsistent and unrelated to cancer development, but also to the constant low concentration of this cytokine in the tumour mass. The associated levels of lipid peroxidation aldehydes, much lower than in control tissue, probably represent a lower stimulus for TGF- $\beta 1$ production in the neoplastic area and thus a favourable condition for neoplastic progression.
\end{abstract}

Abbreviations: TGF- $\beta 1$, transforming growth factor $\beta 1$; TGF- $\beta 1-R I$, TGF- $\beta 1$ receptor type I; TGF- $\beta 1$-RII, TGF- $\beta 1$ receptor type II; MDA, malonaldehyde; HNE, 4-hydroxynonenal; DMEM, Dulbecco's modified Eagle's medium; TBA, thiobarbituric acid; PBS, phosphate buffered saline; DAPI, 4,6-diamidino-2-phenylindole; TUNEL, TdT mediated dUTP nick end labelling. 

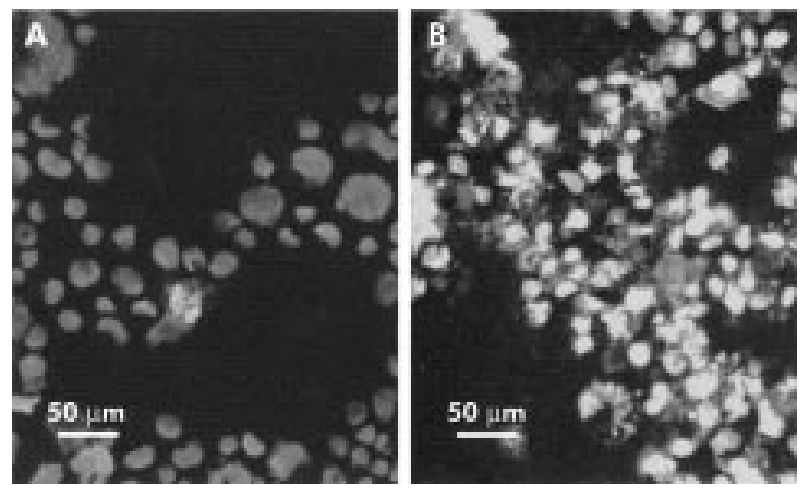

Figure 1 Characterisation of apoptosis in the $\mathrm{CaCo}-2$ cell line using the TdT mediated dUTP nick end labelling (TUNEL) test. (A) Untreated CaCo-2 cells; (B) CaCo-2 cells treated with $10 \mathrm{ng} / \mathrm{ml}$ transforming growth factor $\beta 1$ (TGF- $\beta$ 1) for 48 hours. Fluorescence was detected by a laser scanning confocal microscope (Zeiss): the laser band of excitation was $488 \mathrm{~nm}$ with a $505 \mathrm{~nm}$ long pass filter emission; the lens used was a plan neofluar $40 \times / 0.75$. The image dimension was $325 \mu \mathrm{m} \times 325 \mu \mathrm{m} \times 10 \mu \mathrm{m}$, and the unit scale used was $0.64 \mu^{2}$. The image was elaborated using a LSCM 510 Image Examiner Program (Zeiss). Exciting light intensity, black level, and photomultiplier gain were adjusted on control specimens; the same setting was employed for scanning of experimental material.

expression of TGF- $\beta 1-R I$ and/or RII receptors in 38\% of the group, the receptor system being normally expressed in the remainder who had similar TNM stages. ${ }^{14}$

Hence TGF- $\beta$ receptor deficiency is certainly an important mechanism of tumour progression but it does not appear to be absolutely necessary for this process to develop. Some questions may be posed: are cells with low RI and/or RII mRNA levels completely insensitive to the antiproliferative effect of TGF- $\beta$ ? Is there any change in the net amount of this cytokine within the tumour mass independent of changes in the TGF- $\beta$ receptor system? With regard to the first question, in vitro data on preservation of a significant apoptotic effect of TGF- $\beta 1$ on human colon cancer cells (CaCo-2 cell line), despite low levels of TGF$\beta 1-R I$ and RII, are reported here. In relation to the second question, we previously demonstrated that a major end product of membrane lipid peroxidation, 4-hydroxynonenal (HNE), may contribute significantly towards upregulating both TGF- $\beta 1$ expression and its synthesis. ${ }^{15}$ On the other hand, low lipid peroxidation has consistently been demonstrated in biomembranes from a variety of experimental cancer cell lines and carcinogenesis models (see Dianzani ${ }^{16}$ for a comprehensive review). Thus if a true association exists between the extent of lipid peroxidation reactions and TGF- $\beta 1$ expression, one should also expect a decrease in the level of this cytokine in those types of human cancer found to be resistant to lipid oxidation, with further advantage for cancer cell dedifferentiation and growth. Indeed, in 13 of 15 patients with colon cancer, a significant decrease in the lipid peroxidation product HNE was found in the tumour mass, and it was consistently associated with a net decrease in TGF- $\beta 1$ protein. Only in two extremely advanced cases (G3/T4) were both lipid peroxidation indices and cytokine levels within the control range.

\section{METHODS}

\section{Cell culture}

CaCo-2 human colorectal carcinoma cell line was cultured in Dulbecco's modified Eagle's medium (DMEM) from Gibco BRL Life Technologies Italia Srl (S Giuliano Milanese, Milano, Italy) containing $862 \mathrm{mg} / \mathrm{l}$ L-alanyl-L-glutamine (Glutamax-I), 4500 $\mathrm{mg} / \mathrm{l}$ glucose, and $110 \mathrm{mg} / \mathrm{l}$ sodium pyruvate, supplemented with 20\% fetal bovine serum (Gibco BRL, Life Technologies Italia Srl), and antibiotics/antimycotics (100 units/ml penicillin, $0.1 \mathrm{mg} / \mathrm{ml}$ streptomycin, and $250 \mathrm{ng} / \mathrm{ml}$ amphotericin B from
Sigma Aldrich Italia Srl, Milano, Italy). Cells were cultured in 25 $\mathrm{cm}^{2}$ flasks at $37^{\circ} \mathrm{C}$ in a humidified atmosphere of $5 \% \mathrm{CO}_{2}$ in air and five days after plating (about $70 \%$ confluency) were used for the different experiments. At the end of the treatments, CaCo- 2 cells were harvested by trypsinisation with trypsin-EDTA (2.5 $\mathrm{g} / \mathrm{l}-\mathrm{l} \mathrm{g} / \mathrm{l}$ in $0.9 \%$ sodium chloride) (Sigma Aldrich Italia Srl) and resuspended at 200000 cells/ml in serum and phenol red free DMEM. A total of 80000 cells were collected by cytocentrifugation at $30 \mathrm{~g}$ for seven minutes (Cytospin I; Shandon Inc., Pittsburgh, USA).

\section{Tumour bearing patients}

Fifteen adult patients (eight women, seven men) affected by colon adenocarcinoma were recruited from San Luigi Gonzaga Hospital (Orbassano, Torino, Italy). Mean age of the patients was 60 (10) years.

The different stages of tumour malignancy were defined both in terms of the TMN classification system (T2, five cases; T3, eight cases; T4, two cases) and the histological grading of atypia (G2, 11 cases; G3, four cases).

\section{Tissue sample processing}

The surgically removed segment of colon of each patient was divided into two sections: one zone directly involved in the tumour mass and another distal from the tumour site (normal tissue). Part of the tumour biopsy was embedded in paraffin and part was directly frozen in liquid nitrogen and stored at $-80^{\circ} \mathrm{C}$ until use.

\section{Biochemical markers of lipid peroxidation}

The presence of oxidative damage was assessed in $10 \%(\mathrm{w} / \mathrm{v})$ tissue homogenates prepared from biopsies in $0.1 \mathrm{M}$ Tris $\mathrm{HCl}$ buffer ( $\mathrm{pH}$ 7.4) using a Polytron apparatus (Kinematika $\mathrm{GmbH}$, Luzerna, Switzerland): protein-aldehyde adducts were determined in homogenates as fluorescence exhibited by interaction between protein amino functions and malonaldehyde (MDA) or HNE at wavelengths of 390/460 $\mathrm{nm}$ and $355 / 460 \mathrm{~nm}$, excitation/emission respectively. ${ }^{17}{ }^{18}$

MDA levels were also evaluated in $10 \%(\mathrm{w} / \mathrm{v})$ tissue homogenate specimens using the thiobarbituric acid (TBA) reaction ${ }^{19}$ : homogenates were incubated in a thermostatic shaking bath at $37^{\circ} \mathrm{C}$ for one hour before evaluation.

\section{Western blot analysis of TGF- $\beta 1$ tissue levels}

Tissues were homogenised and after evaluation of protein content by Lowry assay, ${ }^{20}$ samples were normalised-that is, adjusted to achieve an equal amount of protein. For immunoblot analyses, $40 \mathrm{\mu g}$ of total protein were denatured in Laemmli buffer, ${ }^{21}$ loaded on the same $12 \%$ polyacrylamide sodium dodecyl sulphate gel and subjected to electrophoresis under reducing conditions. Comassie blue staining was used to verify appropriate protein normalisation in the electrophoretic run. Proteins were transferred onto nitrocellulose membranes (Hybond ECL; Amersham Pharmacia Biotech GmbH, Germany). Unspecific binding was blocked with $5 \%(\mathrm{w} / \mathrm{v})$ non-fat dried milk in Tris sodium buffer (TBS)-Tween ( $50 \mathrm{mM}$ Tris $\mathrm{HCl}$, pH 7.4, containing $200 \mathrm{mM} \mathrm{NaCl}, 0.05 \% \mathrm{v} / \mathrm{v}$ Tween 20). Blotted membranes were incubated with a polyclonal TGF- $\beta 1$ primary antibody (Santa Cruz Biotechnology, Santa Cruz, California, USA) followed by incubation with peroxidase conjugated polyclonal antirabbit secondary antibodies (Santa Cruz Biotechnology). The immunoblots were developed with the ECL detection system (Amersham Pharmacia Biotech GmbH, Germany) following the manufacturer's directions.

\section{Immunocytohistochemical receptor analysis}

TGF- $\beta 1$ receptors were visualised both on the CaCo- 2 cell line and on tissue sections from patients affected by colon adenocarcinoma. 

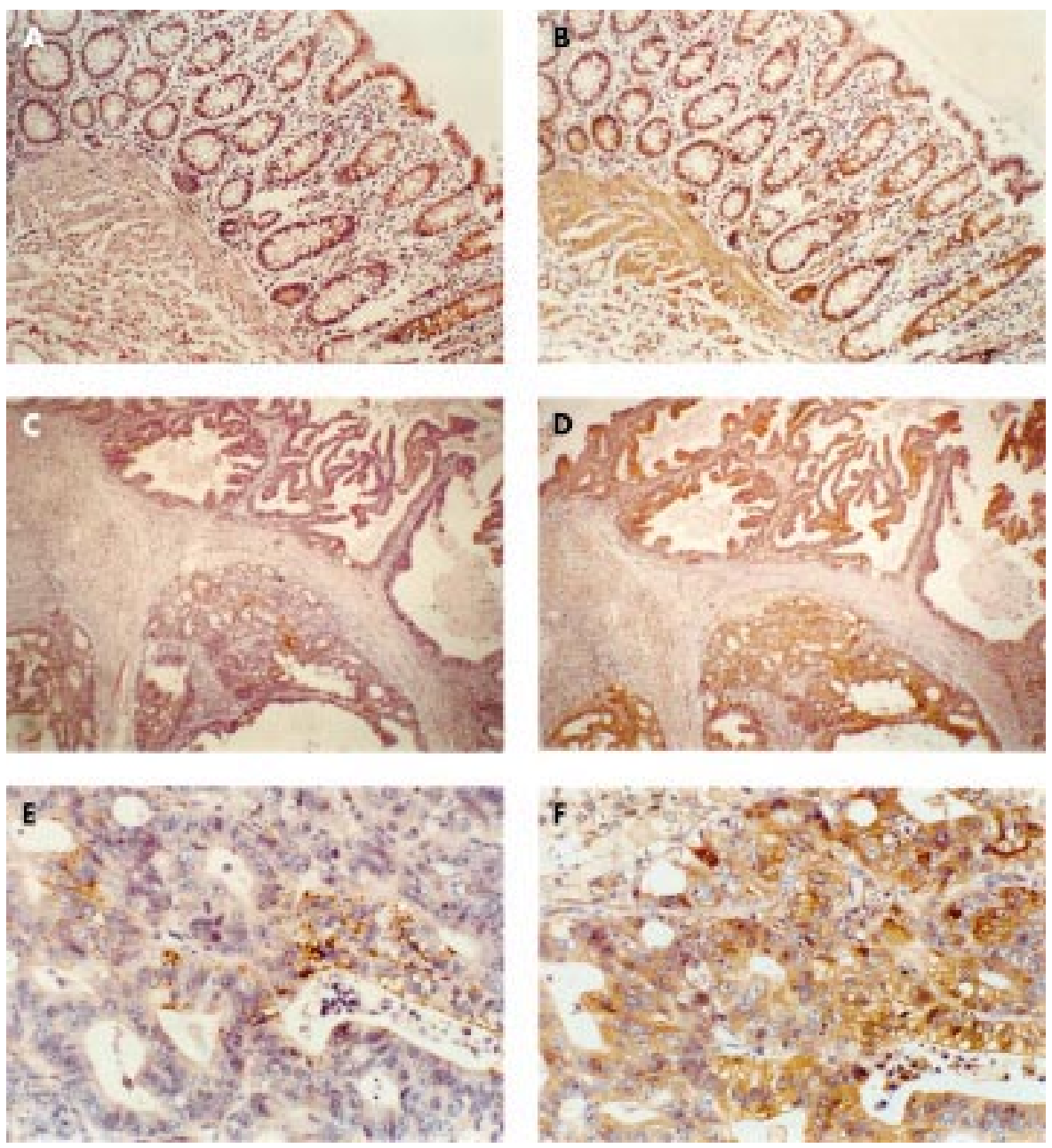

Figure 2 Immunohistochemical analysis of types I and II transforming growth factor $\beta 1$ (TGF- $\beta 1$ ) receptors in colon cancer versus normal mucosa in a representative patient (reported as CP in table 1). Receptors were visualised using an appropriate purified rabbit polyclonal antibody; colour was developed as described in materials and methods. Normal colon mucosa: expression of type I (A) and type II (B) TGF- $\beta 1$ receptors (100x magnification). Colon cancer: expression of type I (C, 40x; E, 250x) and type II (D, 40x; F, 250x) TGF- $\beta 1$ receptors.

CaCo-2 cells were plated and harvested (see cell culture above). After cytocentrifugation the slides were fixed in paraformaldehyde solution ( $4 \%$ in phosphate buffered saline (PBS), $\mathrm{pH} 7.4$ ) for 10 minutes and permeabilised with $0.1 \%$ Triton $\mathrm{X}-100$ in $0.1 \%$ sodium citrate for five minutes at $4^{\circ} \mathrm{C}$. Paraffin was removed from the embedded tissue sections through consecutive passages with pure xylol, 99\% and 95\% ethanol, and water. For antigen retrieval the samples were sunk in $10 \mathrm{mM}$ sodium citrate buffer ( $\mathrm{pH}$ 6.0) and heated in a microwave oven (for three minutes at $750 \mathrm{~W}$ and twice for two minutes at $350 \mathrm{~W}$ ).

In both CaCo-2 cells and tissue specimens, endogenous peroxidase was inhibited by incubation in $0.6 \% \mathrm{H}_{2} \mathrm{O}_{2}$ for 25 minutes. After preincubation with bovine serum albumin in TBS $(0.1 \% \mathrm{w} / \mathrm{v})$ containing 30\% normal porcine serum (v/v) for 20 minutes at room temperature to block non-specific binding, slides were incubated in the presence of the following polyclonal rabbit antibody: $4 \mu \mathrm{g} / \mathrm{ml}$ anti-TGF- $\beta 1-R I(L-21)$ or 8 $\mu g / m l$ anti-TGF- $\beta 1-R I I$ (T-19) (Santa Cruz Biotechnology). Incubation was performed in a humidified chamber at $4^{\circ} \mathrm{C}$ overnight. Negative controls were incubated overnight in the presence of $30 \%$ normal porcine serum $(\mathrm{v} / \mathrm{v})$ alone.

In order to block endogenous avidin and biotin, slides were preincubated for 10 minutes with $0.005 \%$ avidin and for 10 minutes with $0.0005 \%$ biotin (Dako Biotin Blocking System; Dako SpA, Milano, Italy). After this treatment samples were incubated with polyclonal pig antirabbit biotinylated immunoglobulins (1:200 dilution v/v) (Dako SpA), and then with biotin-avidin-peroxidase reagent (ABC complex-HRP; Dako $\mathrm{SpA}$ ) at room temperature for 30 minutes. The bound immunocomplex was visualised by incubation with $0.6 \% 3,3^{\prime}$ diaminobenzidine tetrahydrochloride in TBS containing $0.003 \% \mathrm{H}_{2} \mathrm{O}_{2}$ for $5-10$ minutes. All incubations were preceded by three washes with TBS (Tris NaCl buffer, 50-150 mM, pH 7.6) for five minutes.

Sections were lightly counterstained with Mayer haematoxylin.

\section{Morphological detection of apoptosis induced by TGF- $\beta 1$}

To induce apoptosis, five days after plating (about 70\% confluency) CaCo-2 cells were treated with two repeated doses of TGF- $\beta 1$ ( 5 ng/ml) (Boehringer Mannheim, Roche Diagnostics, Monza, Milano, Italy) at time zero and after 24 hours.

Twenty four hours after the second TGF- $\beta 1$ treatment, cells were harvested from tissue flasks and cytocentrifuged at $30 \mathrm{~g}$ for seven minutes (to obtain 80000 cells/slide).

To detect nuclear staining by 4,6-diamidino-2-phenylindole (DAPI), after collection by cytocentrifugation slides were fixed in ethanol:ether $1: 1(\mathrm{v}: \mathrm{v})$ for 10 minutes, incubated at $37^{\circ} \mathrm{C}$ for 10 minutes in DAPI solution ( $1 \mu \mathrm{g} / \mathrm{ml}$ of absolute methanol, final concentration), and washed with PBS and 96\% ethanol. Analysis of nuclear morphology changes was conducted using a fluorescent microscope with an ultraviolet filter, $630 \times$ magnification. 


\begin{tabular}{|c|c|c|c|c|c|c|c|c|}
\hline \multirow[b]{2}{*}{ Patient } & \multirow[b]{2}{*}{ Sex } & \multirow[b]{2}{*}{ Age (y) } & \multirow[b]{2}{*}{ pTNM } & \multirow{2}{*}{$\begin{array}{l}\text { Histology } \\
\text { (grading) }\end{array}$} & \multicolumn{2}{|c|}{ TGF- $\beta 1-R I^{*}$} & \multicolumn{2}{|c|}{ TGF- $\beta 1-R I I *$} \\
\hline & & & & & $\mathrm{N}$ & $\mathrm{Ca}$ & $\mathrm{N}$ & $\mathrm{Ca}$ \\
\hline BB & $\mathrm{F}$ & 46 & T3N2Ml & $\mathrm{G} 2$ & 54 & 100 & 100 & 100 \\
\hline $\mathrm{CV}$ & M & 50 & T3NOMO & $\mathrm{G} 2$ & 97 & 78 & 93 & 100 \\
\hline DP & $\mathrm{F}$ & 46 & T2NOMO & $\mathrm{G} 2$ & 88 & 59 & 99 & 100 \\
\hline MA & $M$ & 68 & T3NOMO & $\mathrm{G} 2$ & 100 & 98 & 100 & 100 \\
\hline PR & $\mathrm{F}$ & 61 & T3N2Mx & $\mathrm{G} 2$ & 51 & 66 & 82 & 100 \\
\hline TE & M & 80 & T2NOMO & $\mathrm{G} 2$ & 10 & 30 & 8 & 9 \\
\hline$B M$ & M & 59 & T3NOMO & $\mathrm{G} 2$ & 72 & 100 & 100 & 100 \\
\hline CA & M & 56 & T2NOMO & $\mathrm{G} 2$ & 100 & 100 & 100 & 90 \\
\hline DG & $\mathrm{F}$ & 56 & T2NOMO & $\mathrm{G} 2$ & 100 & 14 & 100 & 100 \\
\hline $\mathrm{Pl}$ & $\mathrm{F}$ & 72 & $\mathrm{~T} 2 \mathrm{~N} \times \mathrm{MO}$ & $\mathrm{G} 2$ & 100 & 58 & 88 & 50 \\
\hline$C P$ & M & 69 & T3NIMx & $\mathrm{G} 2$ & 94 & 6 & 100 & 97 \\
\hline CG & $M$ & 59 & T3NOMO & G3 & 90 & 100 & 100 & 100 \\
\hline$M B$ & $M$ & 90 & T3NOMO & G3 & 100 & 6 & 100 & 100 \\
\hline GS & $\mathrm{F}$ & 54 & T4N2M1 & G3 & 100 & 100 & 100 & 67 \\
\hline TZ & $\mathrm{F}$ & 72 & T4NIMO & G3 & 100 & 2 & 100 & 50 \\
\hline
\end{tabular}

$\mathrm{N}$, normal colorectal tissue; Ca, cancerous tissue.

pTNM classification: PT, extent of the primary tumour (T2, tumour invading muscularis propria; T3, tumour invading subserosa; $\mathrm{T} 4$, tumour directly invading other organs and/or visceral peritoneum); $\mathrm{pN}$, regional lymph node metastasis ( $\mathrm{Nx}$, local lymph nodes not evaluable; N0, local lymph nodes without metastasis; N1 metastasis in 1-3 local lymph nodes; N2, metastasis in four or more local lymph nodes); $\mathrm{pM}$, distant metastases ( $M x$, metastases not evaluable; $M 0$, no metastasis; $M 1$, presence of metastases). Histological tumour deviation was graded as follows: G2, moderate; G3, intense.

*The number of positive TGF- $\beta 1$-RI and TGF- $\beta 1$-RIl cells are expressed as a percentage of the total cells examined at $250 \times$ magnification (for each slide, 20 non-consecutive randomised histological fields were evaluated).

Nuclear fragmentation was also detected by the TdT mediated dUTP nick end labelling (TUNEL) technique. Cells were fixed in paraformaldehyde solution (4\% in PBS, $\mathrm{pH} 7.4$ ) for 10 minutes and permeabilised with $0.1 \%$ Triton X-100 in $0.1 \%$ sodium citrate for two minutes at $4^{\circ} \mathrm{C}$. The staining reaction was performed using the "in situ cell death detection kit" from Boehringer Mannheim (Roche Diagnostics SpA, Monza, Italy) and visualised by fluorescein at $488 \mathrm{~nm}$ excitation with 505 $\mathrm{nm}$ long pass filter emission using a laser scanning confocal microscope (LSCM Zeiss, Germany). The objective used was $40 \times$, the dimensions of the optical sections were $325 \mu \mathrm{m} \times 325 \mu$ $\mathrm{m} \times 10 \mu \mathrm{m}$, and the unit scale was $0.64 \mathrm{\mu m}^{2}$.

All slides were sealed with Vectashield H-1000 mounting medium (Vector Lab. Inc., Burlingame, California, USA).

\section{Statistical analyses}

Data are mean (SD). The statistical significance of differences between experimental groups was assessed using the Student's $t$ test.

\section{RESULTS}

\section{TGF- $\beta 1$ induced apoptosis in human colon cancer}

\section{CaCo-2 cell line}

The immunocytochemical semiquantitative analysis for the TGF- $\beta$ receptor system in the CaCo- 2 cell line performed in our laboratory showed low levels of both TGF- $\beta 1$-RI and TGF- $\beta 1$ RII receptors: only $30 \%$ of the randomly examined cancer cells were immunostained when antibodies against type I receptor were employed while about $60 \%$ were immunostained for TGF- $\beta 1-R I I$ receptors (data not shown). Of note, such pronounced TGF- $\beta 1$ receptor deficiency was not sufficient to abolish the proapoptotic effect of the cytokine. In fact, treatment of CaCo-2 cells with an appropriate concentration of TGF- $\beta 1$ (two doses of $5 \mathrm{ng} / \mathrm{ml}$ ) for 48 hours led to marked induction in programmed death, as detected both by DAPI staining of apoptotic bodies (data not shown) and TUNEL, analysed by confocal microscopy (fig 1).
Type I and type II receptor proteins in normal and transformed colon mucosa

Following histopathological and clinical characterisation, the 15 different human colon adenocarcinomas were divided into subgroups according to their TNM classification and degree of dedifferentiation (G1, G2, G3). Five tumours were classified as T2 (G2), six as T3 (G2), two as T3 (G3), and two tumours as T4 (G3). From the paraffin blocks of the individual tumours, $5 \mu \mathrm{m}$ slices were cut for receptor immunostaining using the scattered portions of colon mucosa surrounding the neoplasia as the internal reference. Figure 2 shows a representative immunostaining of TGF- $\beta 1$ receptors in tumour tissue and surrounding normal colon mucosa from one of the 15 cancer patients (reported as CP in table 1). Both type I and type II receptors had a homogenous distribution in normal colon epithelial cells but type II staining was definitely stronger and also extended to the stroma (fig 2A, B). In the adenocarcinoma cells from this clinical case however type I receptors were dramatically reduced in number, and only scattered cells exhibited a fine granular positive reaction (fig 2C, E). In contrast, expression of type II receptors in cancer tissue appeared to be similar to that of normal mucosa (fig 2D, F). Immunohistochemical findings of all other patients are summarised in table 1 . Reduced positivity for TGF- $\beta 1$-RI versus the internal control was evident in tumour samples from seven of 15 patients, independent of the degree of tumour cell growth and differentiation. In contrast, only three cases of all tumours examined showed a low content of type II receptor (TGF- $\beta 1-R I I)$.

\section{Lipid peroxidation markers in human colon adenocarcinoma}

Steady state levels of free MDA, the most commonly employed index of membrane lipid peroxidation, showed a decreasing trend in tumours compared with the surrounding area (normal colon tissue) in T2 tumours, and a statistically significant reduction in T3 tumours, while in the highly dedifferentiated and advanced T4 tumours the amount of tissue 
Table 2 Malonaldehyde (MDA) content and aldehyde-protein adducts in homogenates of biopsy tissues from patients affected by colon adenocarcinoma at different stages of malignancy

\begin{tabular}{llll}
\hline Tumour stage & $\begin{array}{l}\text { MDA content } \\
\text { (nmol/mg protein) }\end{array}$ & $\begin{array}{l}\text { MDA-protein adducts } \\
\text { (AFU/mg protein) } \\
(390 / 460 \mathrm{~nm} \text { ex/em) }\end{array}$ & $\begin{array}{l}\text { HNE-protein adducts } \\
\text { (AFU/mg protein) } \\
(355 / 460 \mathrm{~nm} \text { ex/em) }\end{array}$ \\
\hline Normal tissue (15) & $0.67(0.26)$ & $23(4.0)$ & $30(5.0)$ \\
T2 (5) & $0.52(0.44)$ & $21(4.0)$ & $23(3.4)^{*}$ \\
T3 (8) & $0.29(0.17)^{* *}$ & $16(5.0)^{* *}$ & $21(2.4)^{* *}$ \\
T4 (2) & $0.64(0.17)$ & $24(7.0)$ & $27(4.5)$ \\
\hline
\end{tabular}

Values are mean (SD) (the number of specimens evaluated is indicated in parentheses).

Stage of tumour malignancy was evaluated following the TNM classification.

Significantly different from normal tissue: ${ }^{*} p<0.05,{ }^{*}{ }^{*} p<0.005$.

Protein-aldehyde adducts were determined as fluorescence exhibited by interaction between protein amino

functions and malonaldehyde (MDA) or 4-hydroxynonenal (HNE) at wavelengths of $390 / 460 \mathrm{~nm}$ and

$355 / 460 \mathrm{~nm}$, excitation/emission, respectively.

AFU, arbitrary fluorescence units.

aldehyde was again within the control range. Also, MDA bound to total tissue protein showed a statistically significant decrease only in T3 tumour specimens. Detection of another much more reactive aldehyde stemming from membrane oxidation, HNE, appeared to be a more sensitive marker. In fact,
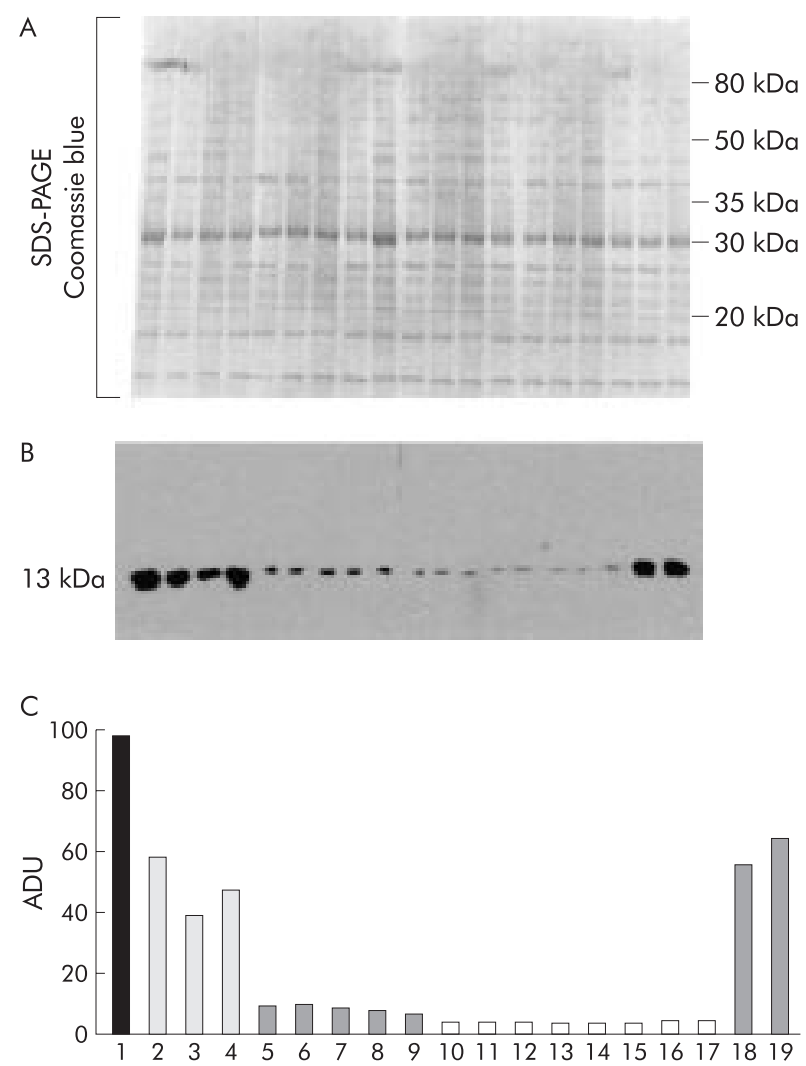

Figure 3 Western blot analysis of transforming growth factor $\beta 1$ (TGF- $\beta 1$ ) protein in patients affected by colon adenocarcinoma at different stages of malignancy. A representative immunoblot. Double protein aliquots ( $40 \mathrm{\mu l}$ each) were taken from biopsy specimens after homogenisation. One aliquot was separated by sodium dodecyl sulphate-polyacrylamide gel electrophoresis (SDS-PAGE) and stained with Comassie blue to verify actual protein normalisation (A). The second protein aliquot was also separated by SDS-PAGE but this time processed with a TGF- $\beta 1$ polyclonal antibody (B). Densitometric analysis of the cytokine level of the single specimens is reported in terms of arbitrary densitometric units (ADU) (C). Samples: 1, colon mucosa from Crohn's disease patient; 2-4, normal colon tissue; 5-9, mucosa from colon adenocarcinoma at T2 (G2) stage; 10-17, mucosa from colon adenocarcinoma at stage T3 (G2); 18-19, mucosa from colon adenocarcinoma at stage T4 (G3).
HNE-protein adducts were found to be significantly reduced in all T2 and T3 tumours (table 2). As in the case of free MDA, the aldehyde-tissue protein adducts detected in the two T4/G3 tumour specimens showed values within the control range.

\section{TGF- $\beta 1$ cytokine level in human colon cancer tissue}

The actual amount of cytokine present in colon adenocarcinoma tissue at different stages of growth and differentiation was determined by the western technique applied on immunoblotted samples. As an internal positive control, a sample was taken from Crohn's disease mucosa which was characterised by an MDA level of $1.25 \mathrm{nmol} / \mathrm{mg}$ protein-that is, about twofold the mean value obtained from normal tissue samples, reported in table 2 . As shown by a representative immunoblot in fig 3, the majority of the specimens were examined together in a single gel for TGF- $\beta 1$ level. Direct densitometric analysis of the immunoblots was made possible by actual deposition of very similar amounts of the sample's protein, as proved by protein staining with Comassie blue. In T2 and T3 colon cancers, almost all with G2 differentiation, TGF- $\beta 1$ content was without exception dramatically lower than that detected in surrounding normal colon mucosa. In agreement with the corresponding extent of lipid peroxidation, the decrease in TGF- $\beta 1$ protein level appeared to be more intense in $\mathrm{T} 3$ than in $\mathrm{T} 2$ tumours.

As in the case of lipid peroxidation markers, the two T4 tumour samples, both with G3 grading, showed a cytokine level similar to control mucosa while the positive control, Crohn's mucosa, showed a net increase in both TGF- $\beta 1$ and lipid oxidation levels.

\section{DISCUSSION}

We found that at least with regard to epithelial cells, the cell type from which colon carcinoma originates, TGF- $\beta 1$ undoubtedly had a growth inhibitory effect. According to a number of studies, TGF- $\beta 1$ exerts its effects through a heteromeric serine/threonine kinase complex involving both TGF- $\beta 1$ receptors I and II. ${ }^{22-27}$ Type I receptors apparently require type II receptors to bind the cytokine, and type II receptors require type I receptors for signal transduction. ${ }^{22}$

However, the properties of these receptors, in particular type I, have not yet been fully characterised, and a differential role has been suggested for RI and RII proteins in the pleiotropic effects of the cytokine. ${ }^{28}{ }^{29}$ Indeed, if it were indispensable for TGF- $\beta 1$ dependent growth inhibition that receptors I and II be fully expressed and acting together, the proapoptotic effect of TGF- $\beta 1$ on CaCo- 2 cells reported here would not be possible. Immunochemical analysis of this cell line with rabbit antibodies raised against antihuman RI and RII TGF- $\beta 1$ protein receptors, confirmed not to cross react with each other, showed that two thirds of neoplastic cells lack the type I receptor while about two thirds still possess type II receptor. 
A previous study on these two receptors in CaCo-2 cells showed decreased TGF- $\beta 1$ binding to type I and especially to type II protein although histochemical analyses were not reported. ${ }^{6}$ Considering the histochemical and functional data together, we may conclude that in this human colon cancer derived cell line, a marked reduction in TGF- $\beta 1$ receptors is probably accompanied by significant loss of receptor affinity. Thus the still present susceptibility of CaCo-2 cells to TGF- $\beta 1$ dependent induction of nuclear fragmentation and apoptosis appears to be important.

In the light of this finding, the marked decrease in TGF- $\beta 1$ protein consistently detectable in T2-T3 (mostly G2) colon cancers is of particular interest: this decrease is presumably a further mechanism of evading cell growth regulation that seems likely to occur in vivo, at least in colon cancer.

The few cases of T4 (G3) tumours recruited do not appear to support this statement as their tissue cytokine levels were within the normal range. However, the high degree of abnormal differentiation of these tumours does not allow correct comparison with less deviated tumours. Of note, transdifferentiation of epithelial cells to mesenchymal cells is one possible event, previously demonstrated in the mammary gland, inducible by TGF- $\beta 1 .{ }^{29}$ Under this hypothetical condition, mesenchymal-like cells would more efficiently secrete TGF$\beta 1$, which in turn might influence the cell's anomalous differentiation in an autocrine loop.

While not strictly comparable with the corresponding findings achieved in CaCo-2 cells, in samples from human colon adenocarcinoma ( 15 patients) the distribution of the type I receptor was also more often affected than that of the type II receptor. But, more importantly, the observed changes did not show any relation to the degree of dedifferentiation and neoplastic progression. A previous study in 22 patients with colorectal cancer reported a decrease in TGF- $\beta 1$ receptors (especially type I) in only eight cases and in addition found no relation with pTNM staging. ${ }^{14}$ In other words, the actual role played by changes in TGF- $\beta 1$ receptors, at least in the development of human colon cancer, still remains uncertain. To date, data available do not support this type of change as a general and primary mechanism of selective neoplastic growth.

As far as the mechanism(s) of altered expression of TGF- $\beta 1$ in the disease cases under observation is concerned, the fairly constant direct correlation of cytokine levels with those of tissue lipid peroxidation is interesting. Decrease in protein was paralleled in all cases by a low index of lipid oxidation. A similar finding was obtained in our laboratory for TGF- $\beta 1$ mRNA and lipid peroxidation in a few cases of human colon cancer. ${ }^{30}$ In T4 (G3) cancers, both cytokine and lipid peroxidation values were in the normal range. In Crohn's disease, TGF- $\beta 1$ protein (this paper) and $\mathrm{mRNA}^{30}$ as well as lipid peroxidation indices, were consistently found to be increased.

There is a significant body of literature on the association between oxidative stress-that is, the prevalence within the cell of oxidising species over the cellular antioxidant potential-and increased fibrogenic cytokines, in particular TGF- $\beta 1$. This association has mainly been found in several disease processes characterised by excessive fibrogenesis, such as atherosclerosis, liver cirrhosis, lung fibrosis, etc (for a comprehensive review see Poli and colleagues $\left.{ }^{31}{ }^{32}\right)$. Furthermore, a causative role of oxidative stress (a major event in which peroxidation of cell membrane lipids occurs) in upregulation of TGF- $\beta 1$ in fibrotic diseases has been demonstrated both in vitro and in an in vivo experimental system: supplementation of cells or animals with suitable amounts of antioxidant not only prevented lipid peroxidation but also inhibited synthesis of the fibrogenic cytokine and quenched the fibrotic process. $^{33-35}$

In conclusion, a consistent and marked decrease in the growth inhibitory cytokine TGF- $\beta 1$ was found in human colon cancer in early-medium phases of progression while changes in expression of the specific receptors appeared less frequent and not closely related to progression of the cancer itself. As maintained susceptibility of colon cancer cells to the proapoptotic effect of TGF- $\beta 1$ appears to some extent feasible, as suggested by the in vitro experiments with the human CaCo- 2 cell line, the net reduction of this cytokine within the tumour mass may be an overall valid mechanism of escape from cell growth regulation. Impairment of membrane lipid oxidation, shown to be associated with tumour progression, would favour this process through reduced availability of aldehyde end products, known to stimulate expression and synthesis of TGF- $\beta 1$.

\section{ACKNOWLEDGEMENTS}

This research was supported by grants from the Italian Ministry of the University (COFIN 1998, 1999, 2000), the National Research Centre, Rome, Target Project in Biotechnology, the Region of Piedmont, and the two universities involved.

\section{Authors' affiliations}

F Biasi, CNR Centre of Immunogenetics and Experimental Oncology, Torino, Italy

L Tessitore, Department of Chemical, Nutritional, Pharmaceutical, and Pharmacological Sciences, University Eastern Piemonte, Novara, Italy

D Zanetti, J C Cutrin, B Zingaro, E Chiarpotto, G Poli, Department of Clinical and Biological Sciences, University of Torino, Italy

N Zarkovic, Rudjer Boskovic Institute, Division of Molecular Medicine, Zagreb, Croatia

G Serviddio, Department of Internal and Public Medicine, University of Bari, Italy

$\mathrm{F}$ Biasi and L Tessitore contributed equally to this work.

\section{REFERENCES}

1 Roberts AB, Sporn MB. Physiological actions and clinical applications of transforming growth factor-beta (TGF-beta). Growth Factors 1993;8:1-9.

2 Massaguè J. TGF $\beta$ signaling: receptors, transducers, and mad proteins. Cell 1996:85:947-50.

3 Geiser AG, Busam KJ, Kim SJ, et al. Regulation of the transforming growth factor-beta 1 and -beta3 promoters by transcription factor Spl Gene 1993;129:223-8

4 Grande JP. Role of the transforming growth factor $\beta$ in tissue injury and repair. PSEBM 1997:214:27-40.

5 Massaguè J, Cheifetz $S$, Laiho $M$, et al. Transforming growth factor-beta. Cancer Surv 1992;12:81-103.

6 Winesett MP, Ramsey GW, Barnard JA. Type II TGF $\beta$ receptor expression in intestinal cell lines and in intestinal tract. Carcinogenesis 1996;17:989-95.

7 Landström M, Eklöv S, Colosetti P, et al. Estrogen induces apoptosis in a rat prostatic adenocarcinoma: association with an increased expression of TGF $\beta 1$ and its type-I and type-II receptors. Int J Cancer 1996:67:573-9.

8 Sun LZ, Wu G, Willson JKV, et al. Expression of transforming growth factor $\beta$ type II receptor leads to reduced malignancy in human breast cancer MCF-7 cells. J Biol Chem 1994;269:26449-55.

9 Kim WS, Park C, Jung YS, et al. Reduced transforming growth factor $\beta$ type II receptor (TGF $\beta R$ III) expression in adenocarcinoma of the lung. Anticancer Res 1999;19:301-6.

10 Markowitz SD, Wang J, Myeroff L, et al. Inactivation of the type II TGF $\beta$ receptor in colon cancer cells with microsatellite instability. Science 1995;268:1336-8

11 Markowitz SD, Roberts AB. Tumor suppressor activity of the TGF-beta pathway in human cancer. Cytochine Growth Factor Rev 1996;7:93-102.

12 Abe Y, Masuda H. Genetic alterations of sporadic colorectal cancer with microsatellite instability, especially characteristics of primary multiple colorectal cancers. J Surg Oncol 2000;74:249-56.

13 Kim WS, Park C, Hong SK, et al. Microsatellite instability (MSI) in non-small cell lung cancer (NSCLC) is highly associated with transforming growth factor- $\beta$ type-ll receptor (TGF- $\beta$ RII) frameshift mutation. Anticancer Res 2000;20:1499-502.

14 Matsushita $M$, Matsuzaki K, Date $M$, et al. Down-regulation of TGF $\beta$ receptors in human colorectal cancer: implications for cancer development. Br J Cancer 1999;80: 194-205.

15 Leonarduzzi G, Scavazza A, Biasi F, et al. The lipid peroxidation end-products 4-hydroxy-2,3-nonenal up-regulates transforming growth factor $\beta 1$ expression in the macrophage lineage: a link between oxidative injury and fibrosclerosis. FASEB J 1997:11:851-7.

16 Dianzani MU. Lipid peroxidation and cancer. Crit Rev Oncol Hematol 1993; 15: 125-47

17 Carini R, Mazzanti M, Biasi F, et al. Fluorescent aldehyde-protein adducts in the blood serum of healthy alcoholics. In: Nordmann $\mathrm{R}_{\text {, }}$ Ribière $\mathrm{C}$, Rouach $\mathrm{H}$, eds. Alcohol toxicity and free radical mechanisms. Advances in biosciences. Oxford: Pergamon Press, 1988 :61-4. 
18 Tsuchida M, Miura T, Mizutani K, et al. Fluorescence substances in mouse and human sera as parameter of in vivo lipid peroxidation. Biochim Biophys Acta 1985;834(71): 196-204.

19 Esterbaver H, Cheeseman H. Determination of aldehydic lipid peroxidation products: malonaldehyde and 4-hydroxynonenal. In: Packer L, Glazer AN, eds. Assay and repair of biological damage. Methods Enzymol 1990; 186:407-21.

20 Lowry OH, Rosenbrough NJ, Farr AL, et al. Protein measurement with the Folin phenol reagent. J Biol Chem 1951;193:265-75.

21 Laemmli UK. Cleavage of structural proteins during the assembly of the head of bacteriophage T4. Nature 1970;227:680-5.

22 Wrana J, Attisano L, Wieser R, et al. Mechanism of the activation of the TGF $\beta$ receptor. Nature 1992;370:341-7.

23 Moustakas A, Lin HY, Henis Yl, et al. The transforming growth factor beta receptors types I, II, and III form hetero-oligomeric complexes in the presence of ligand. J Biol Chem 1993;268:22215-18.

24 Bassing CH, Howe DJ, Segarini PR, et al. A single heteromeric receptor complex is sufficient to mediate biological effect of transforming growth factor beta ligands. J Biol Chem 1994;269:14861-4.

25 Yamashita $\mathbf{H}$, ten Dijke $\mathrm{P}$, Franzen $\mathrm{P}$, et al. Formation of

hetero-oligomeric complexes of type I and type II receptors for growth factor beta. J Biol Chem 1994;269:20172-8.

26 Muramatsu M, Yan J, Tomoda T, et al. A chimeric serine/threonine kinase receptor system reveals the potential of multiple type II receptors to cooperate with transforming growth factor- $\beta$ type I receptor. Mol Biol Cell 1997:8:469-80.
27 Well GR, Gilboa L, Sun $Y$, et al. Transforming growth factor- $\beta$ induces formation of a dithiotreitol-resistant typel/typell receptor complex in live cells. J Biol Chem 1999;274:5716-22.

28 Chen RH, Ebner R, Drynck R. Inactivation of the type II receptor reveals two receptor pathways for the diverse TGF-beta activities. Science 1993:260:1344-8.

29 Miettinen PJ, Ebner R, Lopez AR, et al. TGF beta induced transdifferentiation of mammary epithelial cells to mesenchymal cells: involvement of type I receptors. J Cell Biol 1994;127:2021-36.

30 Chiarpotto E, Scavazza A, Leonarduzzi G, et al. Oxidative damage and transforming growth factor $\beta 1$ expression in pretumoral and tumoral lesions of human intestine. Free Radic Biol Med 1997; 22:889-94.

31 Poli G, Parola M. Oxidative damage and fibrogenesis. Free Radic Biol Med 1997; 21:287-305

32 Poli G. Pathogenesis of liver fibrosis: role of oxidative stress. Mol Aspects Med 2000;21:49-98.

33 Parola M, Muraca R, Dianzani I, et al. Vitamin E dietary supplementation inhibits transforming growth factor $\beta 1$ gene expression in the rat liver. FEBS Lett 1992;308:267-70.

34 Parola M, Pinzani M, Casini A, et al. Stimulation of lipid peroxidation of 4-hydroxynonenal treatment increases procollagen alpha(I) gene expression and synthesis in human liver fat storing cells. BBRC 1993; 194:1044-50.

35 Pietrangelo A, Gualdi R, Casalgrandi G, et al. Molecular and cellular aspects of iron-induced hepatic cirrhosis in rodents. J Clin Invest 1995:95:1824-31.

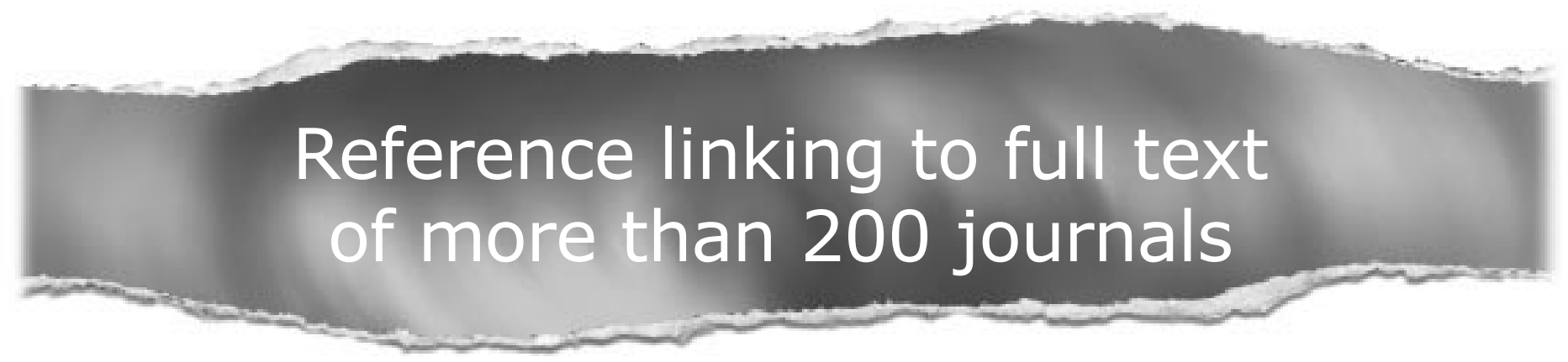

\section{Toll free links}

You can access the FULL TEXT of articles cited in Gut online if the citation is to one of the more than 200 journals hosted by HighWire (http://highwire.stanford.edu) without a subscription to that journal. There are also direct links from references to the Medline abstract for other titles.

\section{www.gutjnl.com}

